\title{
Declining population of the Vulnerable common hippopotamus Hippopotamus amphibius in Bénoué National Park, Cameroon (1976-2013): the importance of conservation presence
}

PAUL SCHOLTE and EMMANUEL IYAH

\begin{abstract}
Populations of the common hippopotamus Hippopotamus amphibius have undergone widespread decline as a result of habitat conversion and hunting for bushmeat and, increasingly, for ivory. North Cameroon holds important populations of large mammals, including the hippopotamus. The species' status and population trend are poorly known, and led CITES to suspend trade in hippopotamus trophies in 2013. Using the methodology of surveys conducted during 1976-1987, we conducted counts of the hippopotamus in Bénoué National Park during the wet season of 2011 and dry season of 2013, and drew on unpublished biannual density counts conducted by the Garoua Wildlife College, Cameroon, during 1989-2010. Counts along the 100 $\mathrm{km}$ stretch of the Bénoué River in the Park indicated a reduction from 400 individuals in 1987 to 188 in 2013. However, linear densities along a 15-32 km stretch in proximity to the Park headquarters and two tourist camps were constant during 1976-2013 (c. 3.7 individuals $\mathrm{km}^{-1}$ ). Hippopotamus distribution was negatively associated with the presence of the camps of gold diggers, which occupied the northern half of the Park. Observations of antelopes suggested they had a comparable distribution, unlike primates, which were distributed relatively evenly. Our results show the importance of year-round conservation presence in the Park, which could be achieved with adequate personnel, a functional road system, and reinforcement of operations in neighbouring sport-hunting areas.
\end{abstract}

Keywords Bénoué, Cameroon, gold diggers, Hippopotamus amphibius, inventory, ivory, poaching

\section{Introduction}

The common hippopotamus Hippopotamus amphibius 1 formerly occurred across most of sub-Saharan Africa but the species has declined, and has been eradicated from some areas, as a result of habitat conversion and hunting for bushmeat and, increasingly, for ivory (Klingel, 2013). Its

Paul Scholte (Corresponding author) Nieuwe Teertuinen 12 C, 1013 LV Amsterdam, The Netherlands. E-mail PaulT.Scholte@gmail.com

Emmanuel Iyah Ecole de Faune de Garoua, Cameroon

Received 5 January 2014. Revision requested 26 June 2014.

Accepted 2 December 2014. First published online 1 February 2016. status in North-Central Africa, spanning southern Chad, north Cameroon and the northern Central African Republic, has been poorly documented in continent-wide reviews (Eltringham, 1999; Klingel, 2013). According to the IUCN Red List (Lewison \& Oliver, 2008) the hippopotamus is widespread in Cameroon, with an estimated population of 500-1,500 individuals, but at the time of the review the population trend was unknown and there was concern for the conservation status of the species in the country. Information on the population status of the hippopotamus is particularly relevant in light of the escalating poaching crisis (e.g. Maisels et al., 2013), with trade in hippopotamus canine tusks (up to $70 \mathrm{~cm}$ long and weighing up to $16 \mathrm{~kg}$ ) becoming increasingly lucrative (Eltringham, 1999). Given the uncertainty about the possible decline in hippopotamus populations in Cameroon, the CITES Standing Committee suspended trade in hippopotamus trophies (CITES, 2013).

A survey in Faro National Park in North Cameroon (Tsi et al., 2011) revealed a hippopotamus population of 600 individuals, and an analysis of surveys carried out in Bénoué National Park revealed there were 400 individuals there in 1987 (Ngog Nje, 1988). The survival of the hippopotamus in North-Central Africa is intrinsically linked to these protected areas, which are part of the northern savannah zone complex that includes, from west to east, Faro National Park, Bénoué National Park and Bouba Ndjida National Park, and 27 safari hunting zones (Njoya, 2008). This 3.35 million ha complex is the last remaining large wildlife conservation refuge in North-Central Africa (Scholte, 2011). The large herbivore fauna of the region $(>2 \mathrm{~kg}$; Scholte, 2011) comprises 17 species, including the most significant population of the largest antelope species, Derby's eland Taurotragus derbianus, on which Cameroon's sport hunting industry depends (Njoya, 2008). So-called hippo lawns, grasslands grazed intensively by hippopotamus, are vital for herbivores as a source of quality forage (Verweij et al., 2006). Surveys undertaken in the savannah zone complex of Chad, the Central African Republic and Cameroon suggest widespread declines of large mammal populations (Scholte, 2011; Bouché et al., 2012) but there is limited quantitative information available for analysis of population trends.

We conducted hippopotamus counts along the entire Bénoué River within Bénoué National Park in the wet season of 2011 and dry season of 2013. Combined with the 
biannual partial counts conducted by the Garoua Wildlife College, Cameroon, these data facilitated an assessment of trends in the hippopotamus population over 37 years; this is one of the longest periods of observation of the species (cf. Klingel, 2013). This assessment also provides insight into the state of the Park, which has limited effective personnel and is under pressure from gold diggers and poachers. We also aim to contribute to the understanding of the continent-wide decline in large mammals, and how longterm environmental changes interact with human pressure and conservation measures (Caro \& Scholte, 2007; Scholte, 2011).

\section{Study area}

Bénoué National Park (180,00o ha; Fig. 1) in North Cameroon has a Guinea-Sudanian climate characterized by a single rainy season during April-September, with mean rainfall of c. 1,200 $\mathrm{mm}$ in the north and c. 1,500 $\mathrm{mm}$ in the south. Towards the end of the dry season temperatures exceed $40^{\circ} \mathrm{C}$. The mostly undulating area, with a few isolated mountains, is covered by wooded savannah dominated by trees of the genera Isoberlinia and Terminalia and a diversified grass layer with Andropogon and Hyparrhenia species (Stark \& Hudson, 1985).

The Park's main geographical feature, the Bénoué River, forms its eastern border over $100 \mathrm{~km}$ between the tributary of Mayo Alim in the south and the Grand Capitaine tourist camp in the north. The river flows south-north, although the flow is underground along long distances during the dry season. During the wet season various intermittent rivers, called mayos, contain water and attract the hippopotamus and other large mammals.

Bénoué National Park is bordered to the east by three sport hunting zones (Fig. 1): Zone 9 (50,072 ha), Zone 3 (55,328 ha) and Zone 2 (75,648 ha). Zone 9 has been abandoned by professional hunters since 2012, and Zones 2 and 3 are marginally operational. Four camps, situated along the Bénoué River, cater for hunting tourists and are also used as a base for anti-poaching operations. Grand Capitaine camp is situated close to the main road in Zone 9. Buffle Noir, the main tourist camp and Park headquarters, is in the south, and there is one camp in Zone 2 and one in Zone 3 (Fig. 1, Plate 1). The Lagdo Reservoir, c. $20 \mathrm{~km}$ north (downstream) of the Park, provides northern Cameroon with hydroelectric energy.

\section{Methods}

We followed the methodology applied by Ngog Nje (1988). All counts except one were conducted in the latter part of the dry season, when the Bénoué River is the Park's only remaining source of water and the area is easily accessible. The

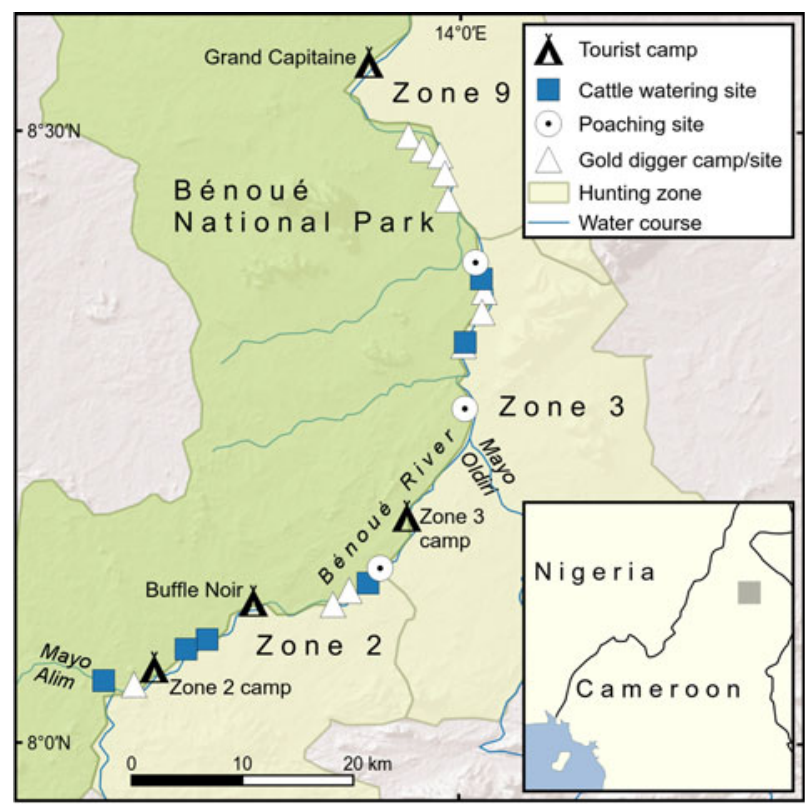

FIG. 1 Human activity recorded in Bénoué National Park, Cameroon, during February-March 2013. A total of 16 gold digger camps and sites were found on the east bank of the Bénoué River but some were very close to each other and therefore cannot be mapped separately.

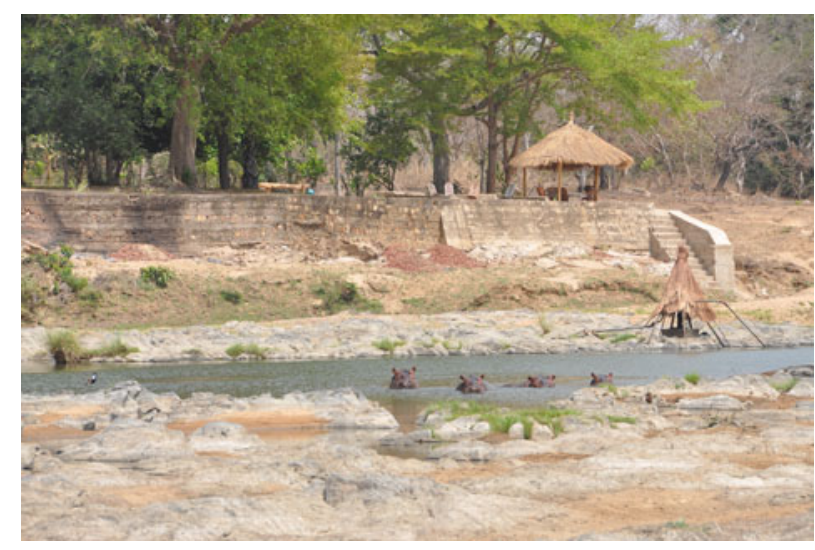

Plate 1 Hippopotamuses Hippopotamus amphibius at the tourist camp in hunting zone 3, along the Bénoué River, Cameroon (Fig. 1), in March 2013. (Photograph by PS)

only exception was the July 2011 count, which was carried out during the rainy season. Observers walked through the riverbed or along its edges, splitting up when the riverbed was too wide to be overseen. Walking speed was 1-4 $\mathrm{km} \mathrm{hr}^{-1}$. When hippopotamuses were observed, in the water or on sandbanks (Plates $1 \& 2$ ), the surveyors halted for 15-30 minutes and counted the number of individuals several times until they reached a consensus.

Total counts in 2011 and 2013 A team of observers, with two permanent members, walked during 07.30-17.30, taking 


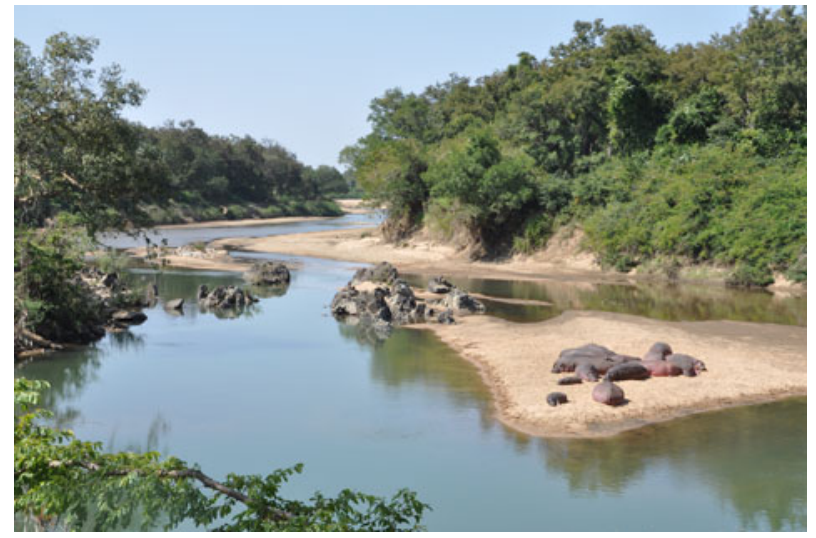

Plate 2 Hippopotamuses on a sand bank, $1 \mathrm{~km}$ downriver from Buffle Noir tourist camp along the Bénoué River, Cameroon (Fig. 1) in December 2012. (Photograph by PS)

a 2 hour break at midday, from Mayo Alim in the south to the Grand Capitaine tourist camp in the north. The surveys were conducted over 9 days in the 2011 rainy season and 6 days in the 2013 dry season. Geographical coordinates of hippopotamus sightings and major landmarks were recorded using a global positioning system. Observations of other wildlife (antelopes and primates) and signs of human presence were also recorded.

Partial counts during 1976-2010 Supervised by the same staff for several consecutive years, teams of 2-3 students from the Garoua Wildlife College conducted surveys every 2 years during 1976-2010. Counts were concentrated on a 15-32 km stretch of the Bénoué River, centred on the Buffle Noir Park headquarters and not extending beyond the two hunting zone camps (Fig. 1). The surveys were carried out in the dry season, in a single day, generally during 09.00-12.00 (Ngog Nje, 1988). From our dry season count in 2013 we determined the number of hippopotamuses along the same stretch of river.

Group size Group size was reported for each observation during 1976-1987 (Ngog Nje, 1988), and in 1989, 2006 and 2013. For comparison the 1989 count was merged with the data for 1976-1987, yielding a total of 173 observations; there were only a total of 46 observations in 2006 and 2013. Group sizes for 2011 were only available aggregated by waterhole, corresponding to c. $0.5 \mathrm{~km}$ stretches of river, and these data were therefore not included in the analysis of group size.

Management efforts We used the number of Park guards, employed by the government and authorized to bear arms, as an indicator of the level of effort by the National Park management (Bruner et al., 2001). We obtained this information from unpublished annual reports of the regional Ministry of Forests and Wildlife.

Modelling To characterize patterns of temporal variation in total counts and linear densities we used a flexible multivariate semi-parametric generalized linear model with a negative binomial error distribution and a log link function. The model fits a smoothed population trend curve and provides $95 \%$ point-wise confidence limits. For more detailed information on the methodology see Ogutu et al. (2011).

\section{Results}

Group size The observations of hippopotamus group size (1976-1989 vs 2006-2013), expressed as a frequency percentage, did not differ significantly $(\mathrm{P}>0.05$, Wilcoxon signed rank test). During the 2006-2013 counts, however, no groups of $>25$ individuals were observed (Fig. 2). The 1976 and 1987 total counts indicated groups of 100 and 110 hippopotamuses, respectively, in the northern part of the Park, at a time when the Mare des 1,000 Hippopotamii was a tourist attraction and was visited regularly by the former president of Cameroon.

Total counts and linear densities The total counts along the $100 \mathrm{~km}$ stretch of the Bénoué River during 2011 and 2013 (Fig. 3) revealed a population decline from 400 individuals in 1987 to 188 in 2013 (Fig. 4). Linear density along the $15-32 \mathrm{~km}$ stretch centred on Buffle Noir remained relatively constant during 1976-2013, with a mean of 3.7 individuals $\mathrm{km}^{-1}$ and a trend line not significantly different from o $(\mathrm{P}=0.98$; Fig. 5).

Observations of other large mammals The distribution of antelope sightings was comparable to that of the hippopotamus, concentrated in the area around the tourist camps. In contrast, primate sightings were distributed evenly along the $100 \mathrm{~km}$ of the Bénoué River within the Park (Table 1).

Human pressures We observed three cases of poaching, with fresh traces of carcasses, including one close to the Mare des 1,00o Hippopotamii, opposite a gold diggers' camp. Meat drying installations indicated the hippopotamuses had been slaughtered for their meat, but the tusk-like canines and incisors had been removed from the skull (Plate 3). We observed 16 sites and camps of gold diggers on the east bank of the Bénoué River, 13 of which were in the north of the Park. (Table 1). Settlements were also found on the west bank of the River, within the Park boundaries, although they 

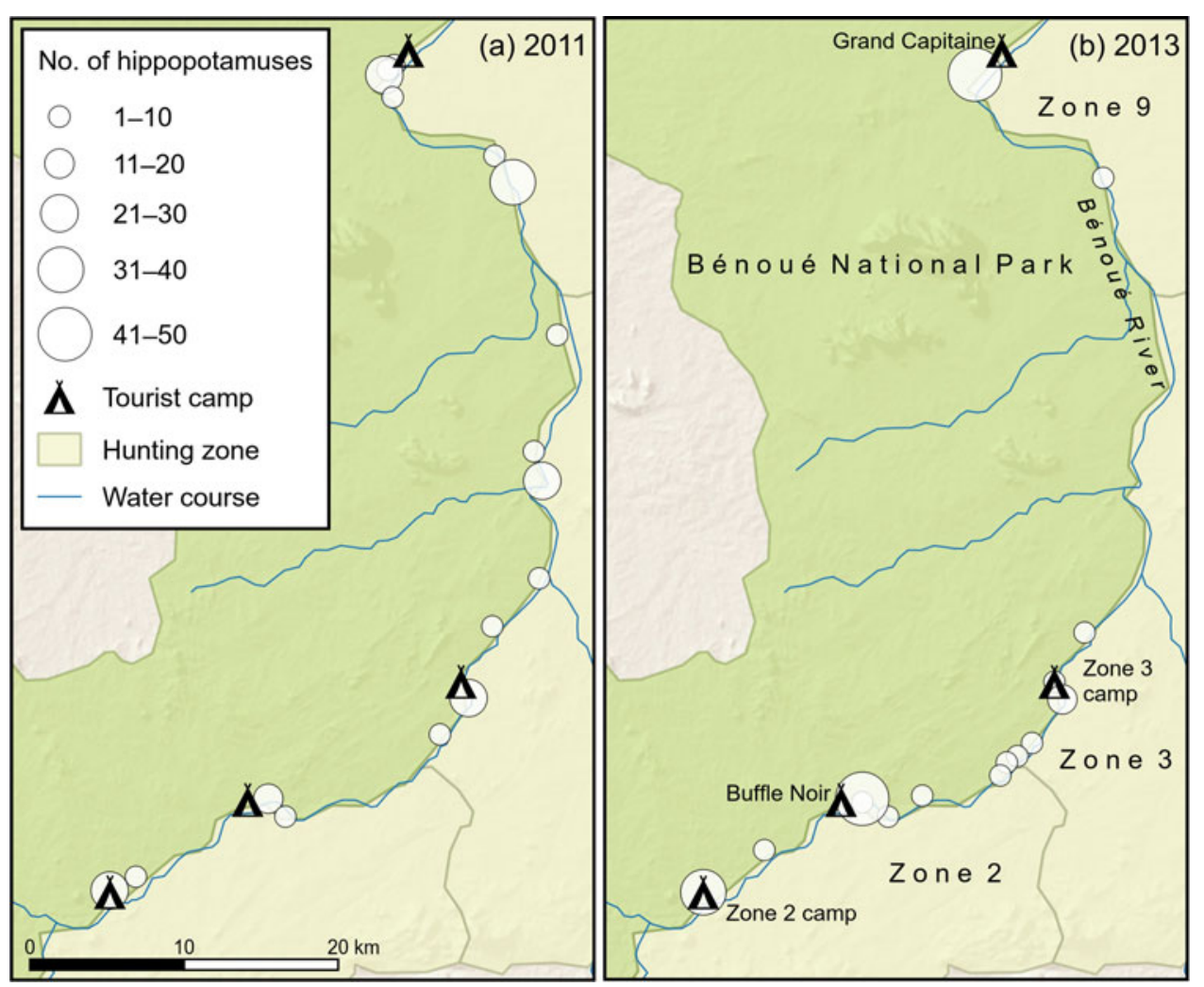

FIG. 2 Distribution of hippopotamus Hippopotamus amphibius in Bénoué National Park, Cameroon (Fig. 1) (a) in July 2011 (rainy season; Maha, 2015) and (b) during FebruaryMarch 2013 (dry season).
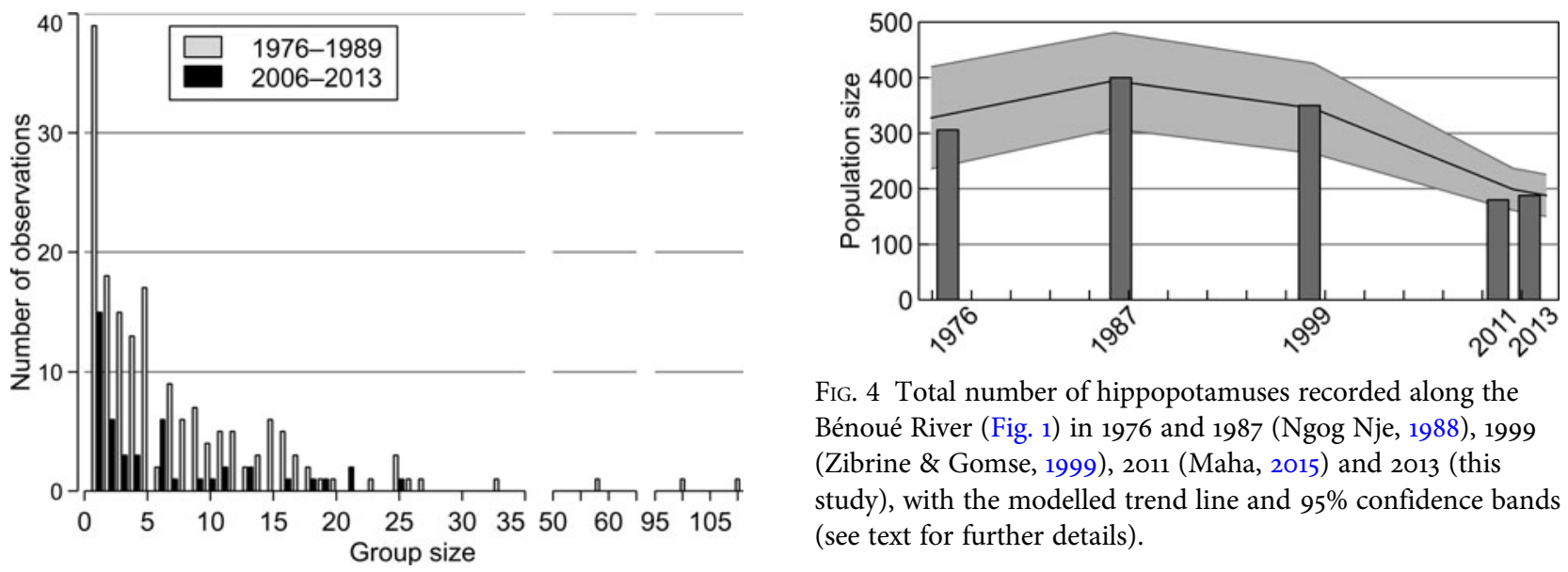

FIG. 4 Total number of hippopotamuses recorded along the Bénoué River (Fig. 1) in 1976 and 1987 (Ngog Nje, 1988), 1999 (Zibrine \& Gomse, 1999), 2011 (Maha, 2015) and 2013 (this study), with the modelled trend line and $95 \%$ confidence bands (see text for further details).

FIG. 3 Frequency of observation of hippopotamus group sizes along the Bénoué River (Fig. 1) during 1976-1989 (Ngog Nje, 1988) and 2006-2013 (Garoua Wildlife College, Cameroon, report, and this study).

were fewer in number. There was a negative association between the presence of gold diggers and hippopotamuses during the 2013 dry season (Table 1, also cf. Figs 1 \& 2b). A number of fishermen were also present, seemingly to provide the gold diggers with fresh fish. Some of the pools that contained hippopotamuses in 2011 were occupied by fishermen using standing nets in 2013 (Table 1). Fulbé pastoralists were also encountered regularly, particularly in

the south of the Park and in hunting zones, using the river to water their cattle (Fig. 1, Table 1).

Management efforts The number of Park guards increased from six in 1962 to almost 50 in the mid 1980s, after which their number declined steadily to 10 in 2011 (Fig. 6). The recruitment of 20 additional guards in 2012 (Fig. 6) does not seem to have led to a reinforced presence in the field. Apart from in the immediate proximity $\left(<_{2} \mathrm{~km}\right)$ of the tourist camps, we did not encounter any conservation personnel during 6 days and nights traversing the Park along the Bénoué River in 2013. In early 2013 roads were 


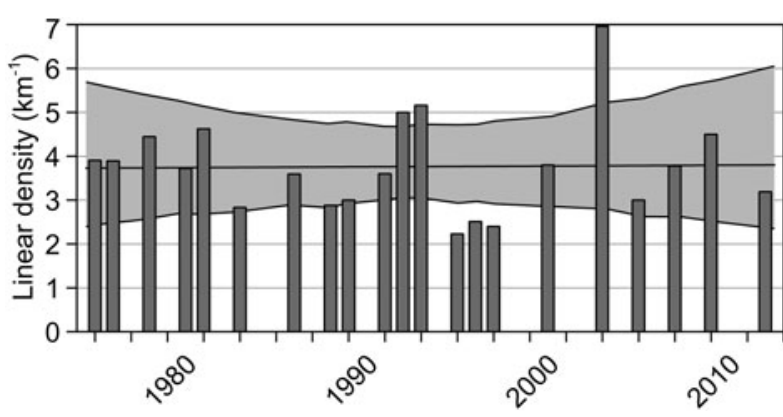

FIG. 5 Linear density of hippopotamuses along a 15-32 km stretch of the Bénoué River in the vicinity of the tourist camps in hunting zone 3, Buffle Noir and hunting zone 2 (Fig. 1) during the dry season, 1976-2013, with the modelled trend line and $95 \%$ confidence bands. The slope of the trend line is not significantly different from o (linear regression $\mathrm{P}=0.98$ ). Sources: 1976-1987 (Ngog Nje, 1988); 1989-2010 (Garoua Wildlife College, Cameroon, reports); 2013 (this study).

repaired for the first time in 5 years, but only in the vicinity $(<15 \mathrm{~km})$ of the Buffle Noir camp.

\section{Discussion}

\section{Reliability of counts}

Few attempts have been made to count hippopotamuses in Bénoué National Park using methods other than total counts (cf. Ngog Nje, 1988), which have been used since 1976. We feel confident of the inter-annual comparability given the constant count period, at the height of the dry season when the only water available was in the Bénoué River, and the use of the same observers (in 2011 and 2013) and supervisors (in earlier years). Stark (1986), not focusing solely on the Bénoué River, used terrestrial transect counts throughout the Park and estimated a population of 235 individuals ( $95 \% \mathrm{CI} \pm 212$ ). The only aerial survey, which targeted elephants Loxodonta africana and did not focus solely on the Bénoué River (Omondi et al., 2008), suggested unrealistically low numbers of hippopotamus (17 in Bénoué National Park, two in Faro National Park and 31 in all hunting zones).

We can only speculate about the reasons for the increase in year-to-year fluctuations in linear hippopotamus density since 1992 (Fig. 5). Cross references with descriptions in count reports of the high (outlying) value in 2004 suggest the counts were reliable. Our impression is that the increase in disturbance had already begun by the early 1990 s, and this is supported by a 1996 internal report of the Garoua Wildlife College.

The statistical models smoothed the trend in population size (total counts; Fig. 4) and the linear density (Fig. 5), indicating that, in the south of the Park, the observed decline in population size was significant and that there was no sigificant trend in linear densities.

\section{Human pressure}

We attribute the apparent disappearance of the hippopotamus from the northern part of the Park between 2011 and 2013, with exception of a waterhole close to the Grand Capitaine tourist camp and one close to a public road (Figs 1 \& 2), to the presence of gold diggers' camps in Zone 9 and the northern part of Zone 3 (Table 1). The gold diggers' camps have an estimated total population of c. 12,00o people, with associated infrastructure including motor tracks, market places and bars (Salamatou, 2013), and poaching of hippopotamus has occurred in the vicinity of these camps. Additional pressure may have come from cattle herders, who until recently would not enter the Park because of the threat of tsetse flies (which can now be deterred using new chemical products). Various studies (e.g. Weladji \& Tchamba, 2003) have reported an increase in human-wildlife conflict in villages west of Bénoué National Park as a result of an influx of immigrants from the Far North region of Cameroon, who have resettled for cotton production. The settlement of gold diggers along the Bénoué River exerts new pressures from the north-east, which remain poorly understood.

\section{Park and hunting zone management}

The settlement of gold diggers, which started in the late 2000s, coincided with a period of virtual absence of Park personnel (Fig. 6), particularly in the north and east of the Park. Park guards were deployed only along the main road in the west and at the Park headquarters, and there appears to have been a lack of motivation and supervision. Prior to the 2013 count the road along the Bénoué River was open but no guards were seen on the $15 \mathrm{~km}$ stretch leading to Buffle Noir. During 2012-2013 all guard operations in Zone 9 were abandoned and gold diggers moved into the area.

Of an accumulated (1983-2003) quota of 509 (set by the Ministry of Forestry and Wildlife) only 75 (15\%) hippopotamuses were hunted legally (Njoya, 2008); during 2010-2012 44 of a quota of 114 (39\%) were hunted legally. In 2013 CITES introduced a ban on the trade in hippopotamus trophies, which was contested by sport hunters (P. Gerard, pers. comm., 2013). How to avoid reducing the viability of sport hunting businesses while continuing to control illegal hunting of hippopotamus and the export of ivory remains a dilemma; see Lindsey et al. (2012) for an analogous discussion on lion hunting.

\section{Changes between 1976-1987 and 2011-2013}

The reduction in the number of hippopotamus from 2011 to 2013 did not come as a surprise as we had received information on poaching and the presence of gold diggers. We had expected to record more hippopotamuses during the dry-season 
TABLE 1 Number of observations of large mammals and signs of major human disturbance along a total of 55 km of the Bénoué River in Bénoué National Park (Fig. 1) within the proximity of tourist camps (Grand Capitaine in the north, and in the south) and along $45 \mathrm{~km}$ of the river not within the proximity of tourist camps (in the north) during 28 February-5 March 2013 , totals for the whole $100 \mathrm{~km}$ of river within the Park, and statistical comparisons ( $\chi^{2}$ test probabilities) of the number of observations in the river sections within and not within the proximity of tourist camps.

\begin{tabular}{|c|c|c|c|c|}
\hline & $\begin{array}{l}\text { Not within the proximity } \\
\text { of tourist camps }\end{array}$ & $\begin{array}{l}\text { Within the proximity } \\
\text { of tourist camps }{ }^{1}\end{array}$ & Total & $\mathrm{P}^{4}$ \\
\hline Hippopotamus Hippopotamus amphibius & 1 & 186 & 187 & $<0.001^{\star * *}$ \\
\hline Antelopes $^{2}$ & 13 & 157 & 170 & $<0.001^{\star * *}$ \\
\hline Primates $^{3}$ & 61 & 57 & 118 & 0.14 \\
\hline Gold digger camps/sites & 13 & 3 & 16 & $0.004^{\star *}$ \\
\hline Poaching sites & 2 & 1 & 3 & 0.450 \\
\hline Fishing sites & 5 & 0 & 5 & $0.013^{*}$ \\
\hline Cattle watering sites & 2 & 4 & 4 & 0.570 \\
\hline
\end{tabular}

${ }^{1}$ Includes the $5 \mathrm{~km}$ stretch of river close to Grand Capitaine tourist camp, and from Mayo Oldiri, c. $10 \mathrm{~km}$ north of the tourist camp in hunting zone 3 , to Mayo Alim, $5 \mathrm{~km}$ south of the tourist camp in hunting zone 2 (Fig. 1)

${ }^{2}$ Kob Kobus kob (57\%), waterbuck Kobus ellipsiprymnus (18\%), bushbuck Tragelaphus scriptus (14\%), red-flanked duiker Cephalophus rufilatus (9\%), hartebeest Alcelaphus buselaphus (1\%) and grey duiker Sylvicapra grimmia (1\%)

${ }^{3}$ Guereza colobus Colobus guereza (45\%), olive baboon Papio anubis (38\%) and tantalus monkey Chlorocebus tantalus (17\%)

${ }^{4 *}, \mathrm{P}<0.05 ;{ }^{* *}, \mathrm{P}<0.01 ;{ }^{* * *}, \mathrm{P}<0.001$

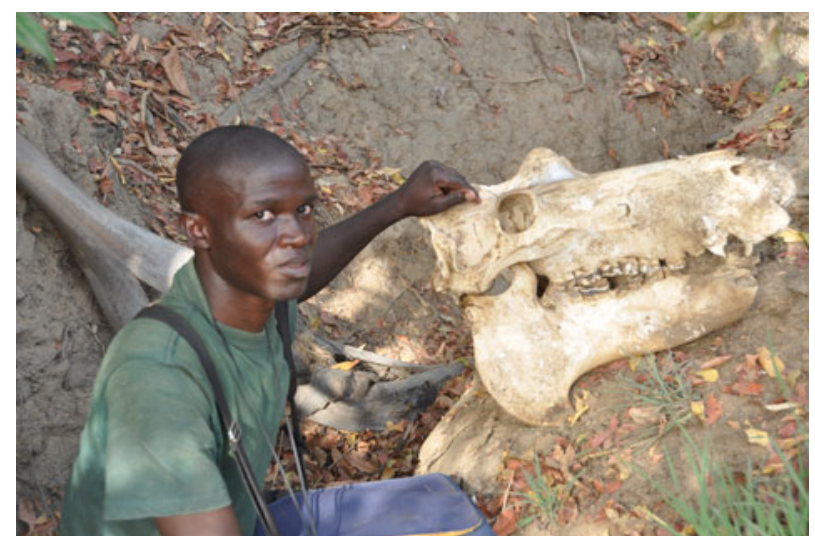

PLATE 3 Skull of poached hippopotamus, with canines and incisors removed (Bénoué National Park, March 2013; photograph by PS, with EI holding skull).

count in 2013 than during the rainy season of 2011, when we would expect the hippopotamuses to disperse throughout the Park because of the availability of water in tributary mayos. Our findings could be interpreted as an accelerated decline. The number of indicators of human disturbance also increased from 2011 to 2013 but this may be biased by the greater accessibility of the area during the dry season.

\section{Linear densities and abundance}

The observed linear density of $3.7 \mathrm{~km}^{-1}$ was stable not only temporally (1976-2013) but also, prior to the decline, along the entire $100 \mathrm{~km}$ stretch of river. Ngog Nje (1988) attributed this to the homogeneity of the surrounding forage lands, with little variation in carrying capacity, and to limited variation in river characteristics.

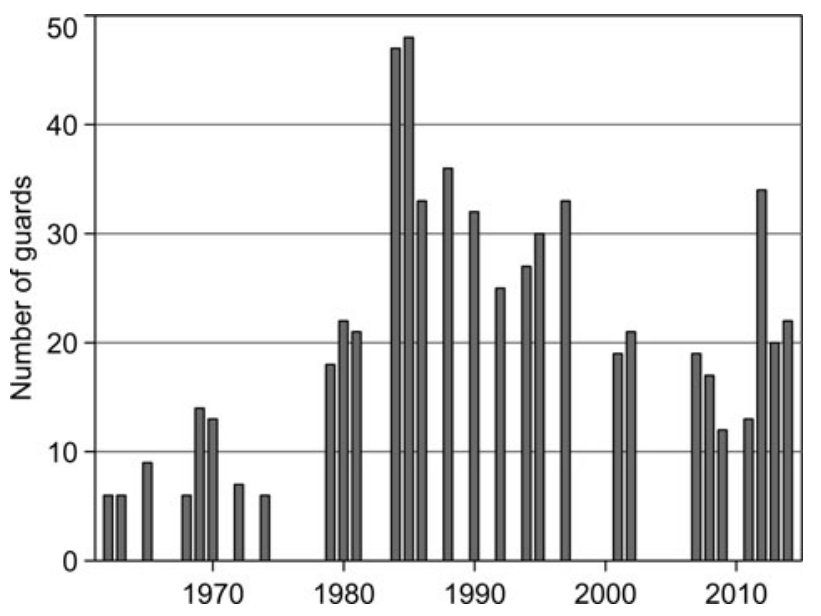

Fig. 6 Numbers of guards in Bénoué National Park during 19622014.

The long-term density of 3.7 individuals $\mathrm{km}^{-1}$ can be compared to incidentally recorded linear densities of $6.5 \mathrm{~km}^{-1}$ (along a $94 \mathrm{~km}$ of river) in Faro National Park to the west (Tsi et al., 2011) and $1.3 \mathrm{~km}^{-1}$ (along a $60 \mathrm{~km}$ of river ) in the Mbam and Djerem National Park, $300 \mathrm{~km}$ to the south (Nchanji \& Fotso, 2007). These densities are low compared with observations from eastern and southern Africa, albeit from the 1980s: $23 \mathrm{~km}^{-1}$ (124 km of the Mara River) in Kenya, $17 \mathrm{~km}^{-1}$ (115 km of the Rufigi River) in Tanzania, 25 and $38 \mathrm{~km}^{-1}(589$ and $165 \mathrm{~km}$, respectively, of the Luangwa River) in Zambia and $40 \mathrm{~km}^{-1}$ (50 $\mathrm{km}$ of the Zambezi River) in Zimbabwe (Eltringham, 1999). This difference may be attributable to the generally nutrient-poor environments of West-Central Africa, which also account for significantly lower ungulate densities (Fritz \& Duncan, 1994). 
In 2008 there were an estimated 125,680-149,230 hippopotamuses in Africa, of which 6,540-10,740 were in West and Central Africa (Lewison \& Oliver, 2008). Whereas areas further west mostly hold smaller and more dispersed populations (Lewison \& Oliver, 2008), the savannah area of Cameroon may have held, until recently, a population larger than the estimated 500-1,500 (Lewison \& Oliver, 2008). Continent-wide declines in hippopotamus populations during the 1990 os were estimated to be $7-20 \%$ (Lewison, 2004, cited in Klingel, 2013). Our results show an accelerated decline of c. 50\% in Bénoué National Park since 1999, with populations outside protected areas probably declining even faster. Elsewhere in North-Central Africa hippopotamus populations, like those of other large mammals, are declining rapidly (Scholte, 2011), and the hippopotamus has reportedly been extirpated from the north of the Central African Republic (Bouché et al., 2012).

\section{Ecological impacts}

The ecological role of the hippopotamus is not well understood, and predicting the consequences of its disappearance remains speculative. The species' grazing lawns, previously studied in Bénoué National Park, are crucial for mesoherbivores such as kob Kobus kob, providing them with quality forage during the wet season (Verweij et al., 2006). Hippopotamuses may also exercise geomorphological impacts by deepening gullies or streams, as observed in the Okavango swamps, Botswana (McCarthy et al., 1998). Evidence of this effect can also be seen around the larger waterholes in Bénoué National Park.

\section{Conclusions}

Our results highlight the importance of year-round conservation efforts for the survival of the hippopotamus and other large mammals. Increasing the number of Park guards, and deploying them effectively in the field (which is linked to the state of the road infrastructure) should therefore be a priority. To reinforce patrolling it will be essential to keep hunting Zones 2 and 3 operational and to reestablish sport hunting in Zone 9. The importance of sport hunting is declining (UICN, 2009), however, and therefore it will be necessary to develop new perspectives for sustainable use of the hunting zones.

Gold digging has become a major conservation challenge for Bénoué National Park and may be the main reason for the local extirpation of the hippopotamus. Artisanal gold digging has caused land degradation and water pollution in other African protected areas (Gandiwa \& Gandiwa, 2012) and should therefore be a cause for concern not only for the Park but also for the downstream Lagdo Reservoir. The Park authorities could use these arguments to mobilize wider support to move the gold diggers out of the Park and hunting zones.

\section{Acknowledgements}

We thank the Bénoué National Park staff for authorization to conduct our surveys, and for their assistance in the field. Without the persistence of students and staff of the Garoua Wildlife College, we would not have had the possibility to draw on 3 decades of surveys. Maha Ngalié coordinated the 2011 survey. Fabrice Hibert and Joseph Ogotu prepared models. Stephany Kersten, Hans Bauer and Joseph Ogutu provided constructive comments on the manuscript.

\section{References}

Bouché, P., Nzapa Mbeti Mange, R.F., Tankalet, F., Zowoya, F., Lejeune, P. \& Vermeulen, C. (2012) Game over! Wildlife collapse in northern Central African Republic. Environmental Monitoring and Assessment, 184, 7001-7011.

Bruner, A.G., Gullison, R.E., Rice, R.E. \& da Fonseca, G.A.B. (2001) Effectiveness of parks in protecting tropical biodiversity. Science, 291, 125-128.

Caro, T. \& Scholte, P. (2007) When protection falters. African Journal of Ecology, 45, 233-235.

CITES (2013) Sixty-third meeting of the Standing Committee, Bangkok (Thailand), 2 March 2013. Review of significant trade. Http://www. cites.org/eng/com/sc/63/E-SC63-14.pdf [accessed 8 August 2013].

Eltringham, S.K. (1999) The Hippos: Natural History and Conservation. Poyser Natural History, London, UK.

Fritz, H. \& Duncan, P. (1994) On the carrying capacity for large ungulates of African savanna ecosystems. Proceedings of the Royal Society of London B, 256, 77-82.

Gandiwa, E. \& Gandiwa, P. (2012) Biodiversity conservation versus artisanal gold mining: a case study of Chimanimani National Park, Zimbabwe. Journal of Sustainable Development in Africa, 14, 29-37.

KLingel, H. (2013) Hippopotamus amphibius. In Common Hippopotamus (eds J. Kingdon \& M. Hoffmann), pp. 68-78. The Mammals of Africa. Vol. VI. Pigs, Hippopotamuses, Chevrotain, Giraffes, Deer and Bovids. Bloomsbury Publishing, London, UK.

LEWISON, R. (2004) IUCN/SSC Hippo Specialist Subgroup. Conservation Report.

LeWISON, R. \& Oliver, W. (2008) Hippopotamus amphibius. In IUCN Red List of Threatened Species v. 2013.2. Http://www.iucnredlist.org [accessed 13 December 2013].

Lindsey, P.A., Balme, G.A., Booth, V.R. \& Midlane, N. (2012) The significance of African lions for the financial viability of trophy hunting and the maintenance of wild land. PLoS ONE, 7(1), e29332. Maha, N. (2015) Étude des populations d'Hippopotames. Structure, croissance et régime alimentaire de l'Hippopotame au Parc National de la Bénoué et sa périphérie (Cameroun). Editions Universitaires Européennes, Saarbrücken, Germany.

Maisels, F., Strindberg, S., Blake, S., Wittemyer, G., Hart, J., Williamson, E.A. et al. (2013) Devastating decline of forest elephants in Central Africa. PLoS ONE, 8(3), e59469.

McCarthy, T.S., Ellery, W.N. \& Bloem, A. (1998) Some observations on the geomorphological impact of hippopotamus (Hippopotamus amphibius L.) in the Okavango Delta, Botswana. African Journal of Ecology, 36, 44-56. 
Nchanji, A.C. \& Fotso, R.C. (2007) Common hippopotamus (Hippopotamus amphibius): a survey on the River Djerem, Mbam-Djerem National Park, Cameroon. Mammalia, 70, 9-13.

Ngog NJe, J. (1988) Contribution à l'étude de la structure de la population des hippopotames (Hippopotamus amphibius L.) au Parc National de la Bénoué (Cameroun). Mammalia, 52, 149-158.

Njoy A, I. (2008) La Chasse au Cameroun. L'Harmattan, Paris, France.

Ogutu, J.O., Owen-Smith, N., Piepho, H.-P. \& Said, M.Y. (2011) Continuing wildlife population declines and range contraction in the Mara region of Kenya during 1977-2009. Journal of Zoology, 285, 99-109.

Omondi, P., Bitok, E.K., Tсhamba, M., Mayienda, R. \& Lambert, B. (2008) Wildlife Species in Faro, Benoué and Bouba Ndjidda National Parks and Adjacent Hunting Blocks in Northern Cameroon. Unpublished report. WWF, Yaounde, Cameroon.

Salamatou, Y. (2013) 12.000 orpailleurs dans le parc national de la Bénoué. L'Oeil du Sahel, 563, 8.

Scholte, P. (2011) Towards understanding large mammal population declines in Africa's protected areas: a West-Central African perspective. Tropical Conservation Science, 4, 1-11.

STARK, M.A. (1986) The numbers, seasonal distribution patterns, densities and biomass of the large herbivores, Bénoué National Park, Cameroon. Mammalia, 50, 341-350.

Stark, M.A. \& Hudson, R.J. (1985) Plant communities'structure in Bénoué National Park, Cameroon: a cluster association analysis. African Journal of Ecology, 23, 21-27.

Tsi, E.A., Tomedi, E.M., Talla, F.N. \& NGuimkeng, D.L. (2011) Status and dynamics of hippopotamus (Hippopotamus amphibius) during the rainy season in Faro National Park Cameroon. Journal of Agriculture and Biological Sciences, 2, 31-37.
UICN (2009) La grande chasse en Afrique de l'Ouest: quelle contribution à la conservation? Https://portals.iucn.org/library/ efiles/documents/2009-074.pdf [accessed 4 January 2014].

Verweij, R.J.T., Verrelst, J., Loth, P.E., Heitköenig, I.M.A. \& Brunsting, A.M.H. (2006) Grazing lawns contribute to the subsistence of mesoherbivores on dystrophic savannas. Oikos, 114, 108-116.

Weladji, R.B. \& TChamba, M.N. (2003) Conflict between people and protected areas within the Bénoué Wildlife Conservation Area, North Cameroon. Oryx, 37, 72-79.

Zibrine, M. \& Gomse., A. (1999) Distribution et dynamique des populations d'hippopotames et des espèces animales liées aux galléries forestiers dans le Parc National de la Bénoué. Internal Report WWFProjet des Savanes Soudanais du Nord, Garoua, Cameroon.

\section{Biographical sketches}

PAUL SCHOLTE is an ecologist leading organizations in conservation and natural resource management in a development context. For 27 years he has worked for governmental (Rwandan, Dutch, German), non-governmental, UN and private organizations. Throughout the 199 os he worked in Waza National Park and other protected areas in North Cameroon. After a decade working in Yemen and Rwanda he returned to Central Africa, where he is trying to build a coalition to respond to the accelerating poaching crisis that is compromising the region's protected areas. EMMANUEL IYAH is a lecturer in zoology and animal ecology at Garoua Wildlife College in North Cameroon. His current research interests are hippopotamus ecology and behaviour. 